CORDEIRO, ECN; RESENDE, JTV; CÓRDOVA, KRV; NASCIMENTO, DA; SAGGIN JUNIOR, OJ; ZEIST, AR; FAVARO, R. 2019. Arbuscular mycorrhizal fungi action on the quality of strawberry fruits. Horticultura Brasileira 37: 437-444. DOI - http://dx.doi.org/10.1590/S0102-053620190412

\title{
Arbuscular mycorrhizal fungi action on the quality of strawberry fruits
}

\author{
Ely Cristina N Cordeiro ${ }^{1} \mathbb{D}$; Juliano Tadeu V de Resende ${ }^{2} \mathbb{D}$; Katielle Rosalva V Córdova ${ }^{3+\mathbb{D}}$; Daniele \\ Aparecida Nascimento ${ }^{3 \mathbb{D}}$; Orivaldo José Saggin Júnior ${ }^{4} \mathbb{D}$; André Ricardo Zeist ${ }^{5 \mathbb{D}}$; Renata Favaro ${ }^{3 \mathbb{D}}$
}

${ }^{1}$ Universidade Federal do Paraná (UFPR), Curitiba-PR, Brasil; elycordeiro@outlook.com; ${ }^{2}$ Universidade Estadual de Londrina (UEL), Londrina-PR, Brasil; jvresende@uol.com.br; ${ }^{3}$ Universidade Estadual do Centro-Oeste(UNICENTRO), Guarapuava-PR, Brasil; kvcordova@ hotmail.com; renatafavaroo@yahoo.com.br; dani123nas@gmail.com; ㅌmbrapa Agrobiologia, Seropédica-RJ, Brasil; orivaldo.saggin@ embrapa.br; ${ }^{5}$ Universidade do Oeste Paulista (UNOESTE), Presidente Prudente-SP, Brasil; andre.zeist@bol.com.br; ${ }^{\dagger}$ in memoriam

\begin{abstract}
The inoculation of arbuscular mycorrhizal fungi (AMF), increasing the rhizospheric influence, might provide higher levels of bioactive compounds. Thus, the objective was to evaluate the influence of the AMF inoculation on the physicochemical components of fruit's quality in field. Strawberry fruits from cultivars Camarosa, Aromas, Camino Real, Monterey, Portola, San Andreas and Albion in 2016, and Camarosa, Camino Real, Monterey and Albion in 2017 were either inoculated or non-inoculated with AMF. The analyzed physicochemical components of fruit's quality were ascorbic acid, titrated acidity, $\mathrm{pH}$, soluble solids, soluble solids/titrated acidity ratio, phenolic compounds, anthocyanins, and firmness. The inoculation with AMF on strawberry plants in field improved the fruit's physicochemical attributes, increasing $\mathrm{pH}$, soluble solids content, soluble solids/titratable acidity ratio and phenolic compounds content in both cultivation years (2016-2017). The inoculation of AMF has improved the characteristics of post-harvest quality in strawberry fruits.
\end{abstract}

Keywords: Fragaria x ananassa, mycorrhiza, inoculation, postharvest.

\begin{abstract}
RESUMO
Ação de fungos micorrízicos arbusculares na qualidade de frutos de morango

A inoculação de fungos micorrízicos arbusculares (FMAs), aumentando sua influência rizosférica, pode induzir maior biossíntese de compostos bioativos em plantas. Dessa forma, objetivou-se avaliar a influência da inoculação de FMAs nos componentes físico-químicos de frutos de cultivares de morangueiro cultivadas a campo. Utilizaram-se frutos das cultivares Camarosa, Aromas, Camino Real, Monterey, Portola, San Andreas e Albion em 2016 e Camarosa, Camino Real, Monterey e Albion em 2017, inoculadas e não inoculadas com FMAs. Avaliaram-se os componentes físicoquímicos ácido ascórbico, acidez titulável, $\mathrm{pH}$, sólidos solúveis, relação sólidos solúveis/acidez titulável (ratio), compostos fenólicos, antocianinas, e firmeza. A inoculação com FMAs de várias cultivares de morangueiros em campo melhorou a qualidade dos frutos, em seus atributos físico-químicos, aumentando o $\mathrm{pH}$, o teor de sólidos solúveis, a relação sólidos solúveis/acidez titulável e o teor de compostos fenólicos em ambos os anos de cultivo (2016-2017). A inoculação de FMAs melhorou as características de qualidade póscolheita de frutos do morangueiro.
\end{abstract}

Palavras-chave: Fragaria x ananassa, micorrizas, inoculação, pós-colheita.

\section{Received on January 29, 2019; accepted on November 7, 2019}

$\mathrm{T}$ he strawberry (Fragaria $\mathrm{x}$ ananassa) has gained prominence as a fruit of global importance (Zeist $\&$ Resende, 2019). It possesses specific characteristics in its composition that please the consumer, such as its intense bright-red color, characteristic odor, soft texture and slightly acidified flavor (Gabriel et al., 2019), which grants it desirable properties for a commodity to be used in several food products.

The arbuscular mycorrhizal fungi (AMFs) are necessarily biotrophic organisms that associate themselves to the plants' roots. These organisms colonize the tissues of the radicular cortex, thus establishing a mutualist symbiosis (Saggin Júnior \& Silva, 2005). This symbiosis may stimulate the synthesis of secondary metabolites, being able to increase the plant's tolerance to biotic and abiotic stress (Pandey et al., 2018). In addition to increasing the accumulation of antioxidant components in plants' tissues, these attributes are potentially beneficial to human health (Baslam et al., 2011).
The inoculation of AMFs increases the concentration of anthocyanins and phenolic compounds in the fruits of the Splendor, Sabrina and Fortuna cultivars in a protected environment (Cecatto et al., 2016). The inoculation of sterilized soil with AMFs and growth-promoting bacteria may improve strawberry physiological quality parameters such as increase in the concentration of sugar and anthocyanins as well as decreasing $\mathrm{pH}$ and malic acid concentration (Todeschini et al., 2018).

Chiomento et al. (2019) have 
inoculated strawberry plant-native AMF communities in strawberry plants from the Albion cultivar grown in sterile sand and concluded that the inoculation has enhanced the fruits' phytochemical quality and promoted a more diffuse radicular system.

However, there are few studies which evaluate the benefit of the inoculation of AMFs in the quality of strawberries grown in field conditions, being therefore necessary to observe if the benefits on the quality of strawberry fruits are maintained when the inoculation is made in the presence of the native microbiota. As such, the objective is to evaluate the influence of AMFs inoculation in physicochemical components in field-grown cultivar strawberry fruits.

\section{MATERIAL AND METHODS}

The experiments were conducted in the Universidade Estadual do CentroOeste in Guarapuava-PR (25'23'01'S, $51^{\circ} 29^{\prime} 46^{\prime \prime} \mathrm{W}$, altitude $\left.1025 \mathrm{~m}\right)$. The local climate is classified as humid subtropical Cfb, by Köppen's classification, with warm summers, winters with frequent frost occurrence, $17^{\circ} \mathrm{C}$ average annual temperature and $1,946 \mathrm{~mm}$ average annual rainfall (Wrege et al., 2011). The local soil is classified as typical Distroferric Bruno Latossoil, according to Embrapa Solos (2013), with very argillaceous texture, resulting from a lava flow known as Trapp.

The experimental outlining for the 2016 experiment was in random blocks with a 2x7 factorial arrangement. The inoculation treatments [plants inoculated with arbuscular mycorrhizal fungi (AMF) and non-inoculated plants] were associated with seven cultivars [Aromas, Monterrey, Portola, San Andreas, Albion (neutral day cultivars), Camarosa and Camino Real (short day cultivars)], disposed in four blocks. Each block corresponded to a patch 1.2 $\mathrm{m}$ width and $0.20 \mathrm{~m}$ height and, in each division twelve saplings of each cultivar were planted, in $30 \times 30 \mathrm{~cm}$ space, in two planting lines, 8 plants being considered the useful division. In 2017, the outlining was made randomly in blocks with $2 \times 4$ factorial arrangement. Treatments consisted both in inoculation and non-inoculation of AMF and cultivars were Monterrey, Albion (neutral day cultivars), Camarosa, Camino Real (short day cultivars), disposed in 6 blocks. Each block consisted of 1.2 $\mathrm{m}$ width by $0.2 \mathrm{~m}$ height, and in each division twelve saplings of each cultivar were planted, in $30 \times 30 \mathrm{~cm}$ spacing in two planting lines, 8 plants being considered the useful division.

The soil was plowed, followed by liming and leveling. Patches were covered with 30 micrometers gauge black polyethylene film (mulching). The base fertilization was made before transplanting, according to the area's soil analysis.

The soil was limed two months before planting, according to the soil analysis, using in the year 2016: 100 $\mathrm{g}$ calcitic lime $/ \mathrm{m}^{2}$. Base fertilization consisted of $50 \mathrm{~g} \mathrm{~K}_{2} \mathrm{O}$ and $50 \mathrm{~g} \mathrm{~N} / \mathrm{m}^{2}$, according to soil analysis. Phosphate fertilization was performed with $50 \%$ of the recommended dose, adding 200 $\mathrm{g} \mathrm{P}_{2} \mathrm{O}_{5}$ in planting and top-dressing, in such way to stimulate the benefit of mycorrhizal fungi which, according to literature, have a more effective action in low P availability conditions.

In the year 2017 we applied 384 $\mathrm{g}$ calcitic lime $/ \mathrm{m}^{2}$, according to soil analysis. In base fertilization we used $50 \mathrm{~g} \mathrm{~K}_{2} \mathrm{O}$ and 48,24 g B/m². Phosphate fertilization was also performed with $50 \%$ of the recommended dose, being $253 \mathrm{~g} \mathrm{P}_{2} \mathrm{O}_{5} / \mathrm{m}^{2}$. Micronutrients were applied by pulverization, every 15 days, using $0.7 \mathrm{~g}$ borax, 0.3 copper hydroxide, $1.8 \mathrm{~g}$ zinc sulphate and $2.9 \mathrm{~g} \mathrm{CAB}$ Plus/ $\mathrm{m}^{2}$.

After performing every pre-planting procedure, before the saplings were transplanted, the cavities received the mycorrhizal inoculant, constituted by several strains of arbuscular mycorrhizal fungi (Tables 1 and 2), being applied in each cavity a dose of the inoculant mentioned in these

Table 1. Composition of arbuscular mycorrhizal fungi strains of the mycorrhizal inoculant used in the 2016 experiment. Guarapuava, UNICENTRO, 2018.

\begin{tabular}{|c|c|c|c|c|c|}
\hline $\begin{array}{l}\text { Strain } \\
\text { code }\end{array}$ & Original strain code & Species & spore/g $\left(n^{0}\right)$ & $\begin{array}{l}\text { spores in inoculant } \\
\text { dose }\left(n^{0}\right)\end{array}$ & $\begin{array}{c}\text { Inoculant dose weight } \\
\text { (g) }\end{array}$ \\
\hline A97 & CNPAB 053 & Acaulospora colombiana & 18 & 10 & 0.56 \\
\hline A96 & CNPAB 052 & Acaulospora morrowiae & 23 & 10 & 0.43 \\
\hline A38 & IES-33 & Acaulospora scrobiculata & 43 & 10 & 0.23 \\
\hline A2 & CNPAB 002 & Dentiscutata heterogama & 27 & 10 & 0.37 \\
\hline A36 & IES-29 & Gigaspora candida & 6 & 10 & 1.67 \\
\hline A20 & CNPAB 020 & Glomus formosanum & 25 & 10 & 0.40 \\
\hline A 80 & CNPAB 038 & Scutellospora calospora & 15 & 10 & 0.67 \\
\hline \multirow[t]{2}{*}{ A75 } & CNPAB 034 & Scutellospora gilmorei & 8 & 10 & 1.25 \\
\hline & & Inoculant mixture & 14 & 80 & 5.58 \\
\hline
\end{tabular}

Results are presented in average $(n=3)$. 
tables. The mycorrhizal inoculant was provided by the Centro de Recursos Biológicos Johanna Döbereiner CRBJD of Embrapa Agrobiologia, located in the municipality of Seropédica-RJ.

During every culture cycle (yearly from April to November) the preventive control of pests and diseases was performed, as well as the adequate irrigation of the saplings by a trickling system according to the plants' needs. Plants were cultivated in a low tunnel system (Henschel et al., 2019), with soil covering (mulching), being opened every day for ventilation and closed during the night and rain periods.

For the physicochemical analysis, in mid-culture cycle during July, 10 ripe fruits $(3 / 4$ of their surface dark red) of each division were collected. The collected fruits were separated according the treatments and according to the cultivar. The determination of soluble solids ( ${ }^{\circ}$ Brix), humidity (\%) and firmness $(\mathrm{N})$ were performed in triplicates $(n=3)$ using fresh, completely ripe fruits, with uniform color and size, the humidity being determined by mass difference and firmness by a workbench penetrometer.

For physicochemical analyses [ascorbic acid (AA) (mg AA $100 \mathrm{~g}^{-1}$ ), titratable acidity (\% of citric acid), $\mathrm{pH}$, titratable acidity/soluble solids ratio, phenolic compounds (gallic acid, mg
$100 \mathrm{~g}^{-1}$ ) anthocyanins (cyanidine-3glycoside, $\left.\mathrm{mg} 100 \mathrm{~g}-{ }^{1}\right)$ ], we used frozen fruits $\left(-18^{\circ} \mathrm{C}\right)$ right after harvest, being analyses performed in triplicate $(\mathrm{n}=3)$ in each division.

The degree of soluble solids was determined in triplicate, with direct reading at room temperature, using a digital refractometer (PAL-1\%, ATAGO model) and expressed in ${ }^{\circ}$ Brix (Barth et al., 2019). The determination of titratable acidity was made in triplicate according to the methodology proposed by the Adolfo Lutz Institute (2005). In order to determine the ratio soluble solids/titratable acidity (SS/AT), the values obtained by reading the soluble solids were divided by the degrees in a percentage of titratable acidity.

For the readings of $\mathrm{pH}$ values a MS Tecnopon digital pH-meter, Mpa-210 model, calibrated accordingly. In order to determine the total phenolic compounds, the extraction of homogenized pulp with ethanol- $80 \%$ was made, being performed in accordance to the spectrophotometric method of FollinCicoauteau, proposed by Woisky \& Salatino (1998). Reading was performed in spectrophotometer at $740 \mathrm{~nm}$ (Cary 60 , Agillent Technologies). The standard curve was made, and results were calculated according to the obtained equation. Results were calculated according to dilution and expressed in gallic acid mg $100 \mathrm{~g}^{-1}$ pulp.

In order to determine the anthocyanin degree, the homogenized pulp extraction was made with ethanol $80 \%$, the $\mathrm{pH}$ difference method being used (Giusti \& Wrolstad, 2001), adapted to strawberries. The samples were analyzed at 510 and $700 \mathrm{~nm}$ in spectrophotometer (Cary 60, Agillent Technologies). Results were expressed in mg cyanidine-3glycoside/100 g sample.

The samples' ascorbic acid (AA) concentration was determined by the AOAC standard titlemetric method (Willians, 1984), modified by Benassi \& Antunes (1988), with addition of $1 \%$ oxalic acid in the samples. After a duration of time in the dark, titration was made with DCFI $0,02 \%(2,6$, dyclorofenol-indofenol) up to the point of color-turning to brick-red. The AA degree was calculated based on the standard ascorbic acid solution and its results expressed in AA $110 \mathrm{~g}^{-1}$.

The humidity degree was determined by mass difference, in samples with approximately $5 \mathrm{~g}$ of fruit, stored in porcelain crucibles, duly identified, subjected to greenhouse drying in forced air circulation at $105^{\circ} \mathrm{C}$, until constant weight and expressed in percentage (IAL, 2005). Pulp firmness was determined by a manual penetrometer with a $7.9 \mathrm{~mm}$ tip, piercing each fruit in two sides and in different positions,

Table 2. Composition of arbuscular mycorrhizal fungi strains of the mycorrhizal inoculant used in the 2017 experiment. Guarapuava, UNICENTRO, 2018.

\begin{tabular}{lllccc}
\hline Strain code & $\begin{array}{c}\text { Original strain } \\
\text { code }\end{array}$ & \multicolumn{1}{c}{ Species } & $\begin{array}{c}\text { spore/g } \\
\left(\mathbf{n}^{\mathbf{0}}\right)\end{array}$ & $\begin{array}{c}\text { spores in inoculant } \\
\mathbf{d o s e}\left(\mathbf{n}^{\mathbf{0}}\right)\end{array}$ & $\begin{array}{c}\text { Inoculant dose } \\
\text { weight }(\mathbf{g})\end{array}$ \\
\hline A92 & CNPAB 048 & Acaulospora foveata & 7 & 10 & 1.43 \\
A94 & CNPAB 050 & Acaulospora mellea & 13 & 10 & 0.77 \\
A96 & CNPAB 052 & Acaulospora morrowiae & 23 & 10 & 0.43 \\
A38 & IES-33 & Acaulospora scrobiculata & 43 & 10 & 0.23 \\
A44 & Inóculo 51 & Claroideoglomuse tunicatum & 17 & 10 & 0.59 \\
A2 & CNPAB 002 & Dentiscutata heterogama & 23 & 10 & 0.43 \\
A36 & IES-29 & Gigaspora candida & 6 & 10 & 1.67 \\
A20 & CNPAB 020 & Glomus formosanum & 25 & 10 & 0.40 \\
A5 & CNPAB 005 & Rhizophagus clarus & 8 & 10 & 1.25 \\
A80 & CNPAB 038 & Scutellospora calospora & 15 & 10 & 0.67 \\
A75 & CNPAB 034 & Scutellospora gilmorei & 8 & 10 & 1.25 \\
\hline \multicolumn{7}{r}{} & Inoculant mixture & 12 & 110 & 9.12 \\
\hline
\end{tabular}

Results are presented in average $(n=3)$. 
so that the fruits would not coincide. Results were expressed in Newtons (N).

In the second cultivation year, the mycorrhizal colonization percentage was analysed in the strawberry plants' roots. Roots were collected at a later stage, after the culture cycle, in order not to interfere in the experimental divisions during production evaluation. Samples were extracted from the roots of three random plants within each division, which were washed, stored in $50 \%$ alcohol and analyzed in the Embrapa Agrobiologia Mycorrhizae Laboratory, using the checkered board counting method from Giovannetti \& Mosse (1980).

The evaluated data were tested concerning the normality and homogeneity of residual variances through the Shapiro-Wilk and Hartley tests, respectively. When the F-test was significant, the average scores were subjected to the Tukey comparison test at $5 \%$ probability, being analyzed through the SISVAR 5.3 software.

\section{RESULTS AND DISCUSSION}

In the two years of cultivation, the cultivars presented higher ascorbic acid (AA) concentration when cultivated without the inoculation of arbuscular mycorrhizal fungi (AMFs) (Tables 3 and 4). We observed that this AA concentration reduction in inoculated plants' fruits was consistent in the two years of conduction and in most cultivars, except only the Portola cultivar. Similar results were found in tomato fruits inoculated with AMFs in reduced fertilization conditions (Bona et al., 2017; Copetta et al, 2011). However, Bona et al. (2015) observed an increase in the AA concentration in strawberry fruits inoculated with AMFs under reduced $\mathrm{N}$ and $\mathrm{P}$ fertilization. Cecatto et al. (2016) verified that AMF inoculation had no effect on the AA concentration of strawberries cultivated in coconut fiber. Todeschini et al. (2018) found same results, cultivating strawberries in sterile ground:sand mixture (2:1).

AA has a great importance for animal and vegetal organisms and its biosynthesis was clarified in 1998, when Wheeler Jones and Smornoff demonstrated in Arabidopsis leaves that L-galactose (L-GAL) and L-galactone1,4-lactone (L-GL) are key precursors of this bioactive compound (Soares et al., 2004). In their study with several vegetables, aiming to investigate ascorbic acid precursors, Soares et al. (2004) confirmed that L-GAL and L-GL are very efficient AA precursors. These precursors are formed from D-glicose, D-frutose, D-manose (D-MAN) in the studied vegetables, phosphorylation being needed so that D-MAN is converted into L-GAL, with a high energetic demand, which, if not supplied, diverts D-MAN to other pathways. This may be why response to AMF inoculation in the fruits AA degree can vary so much, as it depends, among other factors, on the existing availability of $P$ in different substrata, on the presence of a native AMF community and other stressing conditions that may act on the plant.

Response to stressing conditions may lead to the use of AA in the metabolism, diminishing its concentration. AMFs diminish the negative effects of stresses, such as saline and hydric, diminishing the concentration of available AA. In stress conditions occurr the production of reactive species of oxygen (ROS) that cause oxidative damage. As a response to stress, enzymatic and non-enzymatic antioxidants are produced in order to eliminate ROS (Xu et al., 2015). In the non-enzymatic pathway, AA serves directly as a electron donor for reducing ROS, while in the enzymatic way ROS are catalyzed by dismutase superoxide (SOD) in $\mathrm{H}_{2} \mathrm{O}_{2}$ which is reduced in water by catalase (CAT), peroxidase (POD) or by peroxidase ascorbate (APX), reductase glutathione (GR), reductase monodesidroascorbate (MR) and reductase desidroascorbate (DR). In this way AA takes part in the elimination of ROS in both pathways, enzymatic and non-enzymatic (Xu et al., 2015).

In stress conditions, AMFs increase the pigment synthesis and the activity of antioxidizing enzymes, including SOD, CAT, APX and GR (Hashem et al., 2018). According to these authors, in stressed plants, the generated $\mathrm{H}_{2} \mathrm{O}_{2}$ is eliminated through the ascorbate- glutathione cycle, which contains a series of redox reactions that maintain the NADP/NADPH relation and the cellular redox state, preventing the formation of ROS and, thus, protecting the photosynthetic transportation of electrons. The authors verified that the inoculation of AMFs in Cucumis sativus increased the activity of GR and the content of ascorbate (ASA) and glutathione (GSH), which are the main components which control neutralization of ROS.

In 2016, the Camino Real and Camarosa cultivars presented the highest titratable acidity when inoculated with AMFs, while the San Andreas and Albion cultivars presented the highest titratable acidity when there was no AMF inoculation (Table 3). Inoculation promoted the highest titratable acidity in the Camino Real and Portola cultivars, while the titratable acidity was reduced in the San Andreas and Albion varieties. In 2017, the Monterrey cultivar presented a higher titratable acidity than the other cultivars in the presence of inoculation, while in the absence of inoculation the Camarosa and Albion cultivars presented the highest titratable acidity (Table 4). Inoculation promoted higher titratable acidity in the Camino Real and Monterey cultivars, while it reduced titratable acidity in the Camarosa and Albion varieties. Therefore, from these results we concluded the general tendency that inoculation increased titratable acidity of the Camino Real cultivar and reduced that of the Albion cultivar in both cultivation years.

In addition to the intrinsic effects of each cultivar, in the general average of cultivars, titratable acidity did not differ between the inoculated and non-inoculated results in 2016, but in 2017 the titratable acidity was increased by inoculation. Different response in different cultivation years is possible due to different edaphoclimatic conditions. In relation to climate, in 2016 , the rainfall quantity during the culture cycle was considered adequate to the period, however, in 2017, there was an extensive period of rainfall shortage, considered a stress condition to the plant, possibly reducing energetic captivation and inhibiting sugar formation, thus 
increasing the fruits' acidity.

The observed higher acidity is the result of the production level of different organic acids, where the best nutrition and physiological change promoted by the mycorrhiza may change it, bringing a higher produced quantity in these acids' concentration, which can be observed in cultivars that presented higher acidity in treatment with the use of an inoculant.

The fruits' $\mathrm{pH}$ in 2016, except in the Aromas and Camino Real cultivars, was higher in plants inoculated with AMFs, the same being observed in 2017 in the Camarosa and Albion cultivars. Therefore, in both years of cultivation, the cultivars' average results referring to the fruits' $\mathrm{pH}$ demonstrated that higher $\mathrm{pH}$ (lower acidity) when the AMFs were inoculated (Tables 3 and 4). The registered $\mathrm{pH}$ values varied between 3.40 and 0.77 , which is less acid compared to what was verified in other studies (Cecatto et al., 2016; Todeschini et al. 2018), given that AMF inoculation has collaborated with the decrease in acidity. The fruit's $\mathrm{pH}$ is a characteristic that presents a certain relativity when it concerns pulp consumption. For in natura consumption, lower acidity makes the fruit more attractive to consumers which prefer less sharp fruits, but for processing, higher acidity diminishes costs, mainly in the final sterilization of the processed product (Gabriel et al., 2019).

Both, in 2016 and 2017, the absolute majority of cultivars presented a higher degree of soluble solids when inoculated with AMFs (Tables 3 and 4). Considering the average cultivars scores, in both years it was observed that fruits coming from AMF-inoculated plants presented pulps with higher ${ }^{\circ} \mathrm{Brix}$ value than non-inoculated plants (Tables 3 and 4).

In 2016, the degree of soluble solids varied between $6.30-8.90^{\circ}$ Brix. In 2017 , it varied between $6.56-11.96^{\circ} \mathrm{Brix}$, there being, thus, a great variation of this attribute, especially in the second year of cultivation. The soluble solid proportions are a very important attribute for acceptance of the strawberries among consumers (Cecatto et al., 2013). According to these authors, there's a variation for this attribute according to the cultivars and the cultivation edaphoclimatic conditions, that justify the observed variation. Generally, when there's a drought, mychorrized plants will absorb more water and dilute sugar. In conditions of good water availability, mychorrized plants tend to present more sugar by presenting a higher photosynthetic yield and higher nutrition, which probably was the case of the present study.

The SST/AT ratio evaluation for 2016 showed variation among the cultivars. Although most cultivars had

Table 3. Physical and chemical analysis results of strawberry cultivars with mycorrhiza in 2016. Guarapuava, UNICENTRO, 2018.

\begin{tabular}{|c|c|c|c|c|c|c|c|c|}
\hline \multirow[t]{2}{*}{ Cultivars } & \multicolumn{2}{|c|}{$\begin{array}{l}\text { Ascorbic acid (AA) } \\
(\text { mg AA 100g-1) }\end{array}$} & \multicolumn{2}{|c|}{$\begin{array}{c}\text { Titratable acidity (\% } \\
\text { citric acid) }\end{array}$} & \multicolumn{2}{|c|}{ pH } & \multicolumn{2}{|c|}{ Soluble solids $\left({ }^{\circ}\right.$ Brix $)$} \\
\hline & w/inoc. & wo/inoc. & w/inoc. & wo/inoc. & w/inoc. & wo/inoc. & w/inoc. & wo/inoc. \\
\hline Camarosa & $79.76 \mathrm{aB}$ & $84.35 \mathrm{bA}$ & $0.89 \mathrm{bA}$ & $0.91 \mathrm{cA}$ & $3.77 \mathrm{aA}$ & $3.44 \mathrm{deB}$ & $8.90 \mathrm{aA}$ & $7.20 \mathrm{aB}$ \\
\hline Aromas & $40.80 \mathrm{eB}$ & $58.56 \mathrm{dA}$ & $0.81 \mathrm{dA}$ & $0.80 \mathrm{eA}$ & $3.75 \mathrm{aA}$ & $3.75 \mathrm{aA}$ & $6.47 \mathrm{dA}$ & $6.30 \mathrm{bA}$ \\
\hline Camino Real & $57.51 \mathrm{~dB}$ & $75.62 \mathrm{cA}$ & $1.08 \mathrm{aA}$ & $0.87 \mathrm{~dB}$ & $3.50 \mathrm{bA}$ & $3.47 \mathrm{cdeA}$ & $6.40 \mathrm{~dB}$ & $7.07 \mathrm{aA}$ \\
\hline Monterey & $64.70 \mathrm{cB}$ & $69.57 \mathrm{cA}$ & $0.87 \mathrm{bcA}$ & $0.86 \mathrm{dA}$ & $3.71 \mathrm{aA}$ & $3.52 \mathrm{cdB}$ & $7.70 \mathrm{bA}$ & $6.30 \mathrm{bB}$ \\
\hline Portola & $71.30 \mathrm{bA}$ & $71.92 \mathrm{cA}$ & $0.85 \mathrm{cA}$ & $0.74 \mathrm{fB}$ & $3.56 \mathrm{bA}$ & $3.40 \mathrm{eB}$ & $6.93 \mathrm{cdA}$ & $6.33 \mathrm{bB}$ \\
\hline San Andreas & $37.81 \mathrm{eB}$ & $62.60 \mathrm{dA}$ & $0.86 \mathrm{bcB}$ & $1.08 \mathrm{aA}$ & $3.76 \mathrm{aA}$ & $3.57 \mathrm{bcB}$ & $7.97 \mathrm{bA}$ & $6.33 \mathrm{bB}$ \\
\hline Albion & $30.50 \mathrm{Fb}$ & $90.88 \mathrm{aA}$ & $0.79 \mathrm{~dB}$ & $1.03 \mathrm{bA}$ & $3.77 \mathrm{aA}$ & $3.63 \mathrm{bB}$ & $7.43 \mathrm{bcA}$ & $6.73 \mathrm{abB}$ \\
\hline Average & $54.62 \mathrm{~B}$ & $73.36 \mathrm{~A}$ & $0.88 \mathrm{~A}$ & $0.90 \mathrm{~A}$ & $3.69 \mathrm{~A}$ & $3.45 \mathrm{~B}$ & $7.40 \mathrm{~A}$ & $6.60 \mathrm{~B}$ \\
\hline \multirow[t]{2}{*}{ CV (\%) } & \multicolumn{2}{|c|}{3.88} & \multicolumn{2}{|c|}{1.61} & \multicolumn{2}{|c|}{1.24} & \multicolumn{2}{|c|}{3.47} \\
\hline & \multicolumn{2}{|c|}{ Ratio (SST/AT) } & \multicolumn{2}{|c|}{$\begin{array}{c}\text { Phenolics (mg gallic ac. } \\
\left.\qquad 100 \mathrm{~g}^{-1}\right)\end{array}$} & \multicolumn{2}{|c|}{$\begin{array}{c}\text { Anthocyanins (mg } \\
\left.\mathbf{1 0 0 g}^{-1}\right)\end{array}$} & \multicolumn{2}{|c|}{ Firmness (N) } \\
\hline Camarosa & $9.97 \mathrm{aA}$ & $7.90 \mathrm{abB}$ & $164.47 \mathrm{bcB}$ & $168.01 \mathrm{aA}$ & $23.28 \mathrm{abA}$ & $18.24 \mathrm{bB}$ & $14.08 \mathrm{abA}$ & $10.83 \mathrm{abB}$ \\
\hline Aromas & $8.01 \mathrm{dA}$ & $7.83 \mathrm{abA}$ & $166.78 \mathrm{bA}$ & $160.73 \mathrm{bB}$ & $28.12 \mathrm{aA}$ & $24.02 \mathrm{aB}$ & $14.43 \mathrm{aA}$ & $7.45 \mathrm{cB}$ \\
\hline Camino Real & $5.92 \mathrm{eB}$ & $8.13 \mathrm{aA}$ & $164.24 \mathrm{bcA}$ & $153.55 \mathrm{cB}$ & $20.16 \mathrm{bcB}$ & $27.28 \mathrm{aA}$ & $11.46 \mathrm{bcA}$ & $10.39 \mathrm{abA}$ \\
\hline Monterey & $8.88 \mathrm{bcA}$ & $7.34 \mathrm{bcB}$ & $161.75 \mathrm{bcA}$ & $153.59 \mathrm{cB}$ & $24.84 \mathrm{abA}$ & $12.90 \mathrm{cB}$ & $8.97 \mathrm{cdA}$ & $9.00 \mathrm{bcA}$ \\
\hline Portola & $8.12 \mathrm{cdA}$ & $8.54 \mathrm{aA}$ & $172.27 \mathrm{aA}$ & $152.56 \mathrm{cB}$ & $17.52 \mathrm{cB}$ & $22.44 \mathrm{abA}$ & $12.48 \mathrm{abA}$ & $11.93 \mathrm{aA}$ \\
\hline San Andreas & $9.23 \mathrm{abA}$ & $5.88 \mathrm{~dB}$ & $164.56 \mathrm{bcA}$ & $150.82 \mathrm{cdB}$ & $20.62 \mathrm{bcA}$ & $18.86 \mathrm{bA}$ & $14.07 \mathrm{abA}$ & $10.43 \mathrm{abB}$ \\
\hline Albion & $9.38 \mathrm{abA}$ & $6.56 \mathrm{cdB}$ & $161.12 \mathrm{cA}$ & $146.61 \mathrm{~dB}$ & $16.84 \mathrm{cB}$ & $22.74 \mathrm{abA}$ & $8.30 \mathrm{dA}$ & $8.82 \mathrm{bcA}$ \\
\hline Average & $8.50 \mathrm{~A}$ & $7.45 \mathrm{~B}$ & $165.03 \mathrm{~A}$ & $155.12 \mathrm{~B}$ & $21.62 \mathrm{~A}$ & $20.92 \mathrm{~A}$ & $11.97 \mathrm{~A}$ & $9.83 \mathrm{~B}$ \\
\hline $\mathrm{CV}(\%)$ & \multicolumn{2}{|c|}{3.77} & \multicolumn{2}{|c|}{1.31} & \multicolumn{2}{|c|}{9.03} & \multicolumn{2}{|c|}{9.37} \\
\hline
\end{tabular}

$\mathrm{w} /$ inoc $=$ with inoculant; wo/inoc $=$ without inoculant. Results are presented in average $(n=3)$. Same lowercase letters in the column and uppercase letters in the line do not differ significantly, Tukey test $(\mathrm{p} \leq 0,05)$. 
a ratio increase by $\mathrm{AMF}$ inoculation. The Camino Real cultivar presented an opposite behavior. In 2017, the behavior was similar, Camino Real being the only one in which the ratio was unaffected by inoculation. Considering the general cultivars' average, in both years, inoculation has promoted higher ratio values in strawberry fruits (Tables 3 and 4). The ratio between sweetness and sharpness affects the fruits' aroma and flavor, being considered an optimal quality indicator in strawberries (Todeschini et al., 2018). The ratio varies with genotype, maturation stage and edaphoclimatic factors (Gabriel et al., 2019), given that, in the present work, the inoculation clearly favored sugar accumulation in relation to organic acids. Sugars, mainly fructose, glycose and saccharose are involved in the fruits maturation, anthocyanin synthesis, and particularly fructose is a precursor of the furanones volatile compounds, which contribute to aroma (Todeschini et al., 2018). Organic acids, on their turn, in particular the citric acid in strawberries, are involved in the maintenance of nutritional value, in the fruits' quality and in pectin jellification process.

Concerning the analysis of phenolic compounds in strawberries, in both years a tendency of a higher quantity of phenolics was verified in AMFinoculated plants. The sole exception was Camarosa cultivar in 2016, but its behavior was opposite in 2017. The general average of the cultivars confirms this tendency, showing that both in 2016 and in 2017, there were more phenolic compounds in the fruits of strawberry plants that were inoculated with AFMs (Tables 3 and 4).

According to Fernandez-Lara et al. (2015), phenolic compounds are the main bioactive components by the strawberries' antioxidizing properties. They are as well punctually responsible for the organoleptic characteristics such as flavor, texture, aroma, color and appearance. Thus, the importance of AMF inoculation is highlighted in order for the fruits to present higher phenolic compound proportions.

According to Ceccato et al. (2016), inoculation with AMFs increased by 19 and $13 \%$, respectively, the quantity of phenolic compounds in the strawberry cultivars Albion and Aromas when compared to fruits of non-inoculated plants. In this study, a phenolic compound increase for these cultivars was also observed, the increase being 11 and 5\%, respectively in 2016 (Table 3). In 2017, there was an increase of $30 \% ; 17 \%, 12 \%$ and $9 \%$ for the Albion, Camino Real, Camarosa and Monterey cultivars, respectively, for inoculated plants in comparison to noninoculated ones (Table 4), thus showing the effectivity of AMF inoculation for the improvement of this fruit quality characteristic.

Concerning the anthocyanin degree in 2016, the AMF-inoculated fruits of the Camarosa, Aromas and Monterrey cultivars showed higher values in relation to non-inoculated plants (Table 3). An opposite behavior was observed for cultivars Camino Real, Portola and Albion. The evaluation of anthocyanins of fruits cultivated in 2017 has shown a higher value for AMF-inoculated plants from the Monterey and Albion cultivars, but an opposite behavior from the Camarosa cultivar (Table 4). That is, the Camarosa and Albion cultivars behaved contrarily to inoculation between 2016 and 2017. This indicates a large variability in induced response by the inoculation of this variable in relation to edaphoclimatic variations. By observing the general average of cultivars, inoculation has increased the anthocyanin degree only in 2017 (Table

Table 4. Physical and chemical analysis results of strawberry cultivars with mycorrhiza in 2017. Guarapuava, UNICENTRO, 2018.

\begin{tabular}{|c|c|c|c|c|c|c|c|c|}
\hline \multirow[t]{2}{*}{ Cultivars } & \multicolumn{2}{|c|}{$\begin{array}{l}\text { Ascorbic acid (AA) } \\
\left(\text { (mg AA } 100 \mathrm{~g}^{-1}\right)\end{array}$} & \multicolumn{2}{|c|}{$\begin{array}{l}\text { Titratable acidity } \\
\text { (\% citric acid) }\end{array}$} & \multicolumn{2}{|c|}{ pH } & \multicolumn{2}{|c|}{$\begin{array}{c}\text { Soluble solids } \\
\left({ }^{\circ} \text { Brix }\right)\end{array}$} \\
\hline & w/inoc. & wo/inoc. & w/inoc. & wo/inoc. & w/inoc. & wo/inoc. & w/inoc. & wo/inoc. \\
\hline Camarosa & $53.62 \mathrm{cB}$ & $91.82 \mathrm{abA}$ & $0.98 \mathrm{bB}$ & $1.18 \mathrm{aA}$ & $3.67 \mathrm{aA}$ & $3.39 \mathrm{~dB}$ & $9.20 \mathrm{cA}$ & $7.70 \mathrm{aB}$ \\
\hline Camino Real & $52.62 \mathrm{cB}$ & $88.42 \mathrm{bA}$ & $0.98 \mathrm{bA}$ & $0.85 \mathrm{cB}$ & $3.49 \mathrm{cA}$ & $3.50 \mathrm{bA}$ & $7.86 \mathrm{dA}$ & $6.56 \mathrm{cB}$ \\
\hline Monterey & $62.81 \mathrm{bB}$ & $90.82 \mathrm{abA}$ & $1.33 \mathrm{aA}$ & $1.00 \mathrm{bB}$ & $3.68 \mathrm{aA}$ & $3.65 \mathrm{aA}$ & $11.96 \mathrm{aA}$ & $6.80 \mathrm{bcB}$ \\
\hline Albion & $77.59 \mathrm{aB}$ & $97.26 \mathrm{aA}$ & $1.00 \mathrm{bB}$ & $1.17 \mathrm{aA}$ & $3.56 \mathrm{bA}$ & $3.44 \mathrm{cB}$ & $10.23 \mathrm{bA}$ & $7.13 \mathrm{bB}$ \\
\hline Average & $61.53 \mathrm{~B}$ & $92.07 \mathrm{~A}$ & $1.08 \mathrm{~A}$ & $1.05 \mathrm{~B}$ & $3.60 \mathrm{~A}$ & $3.49 \mathrm{~B}$ & $9.81 \mathrm{~A}$ & $7.05 \mathrm{~B}$ \\
\hline \multirow[t]{2}{*}{ CV (\%) } & \multicolumn{2}{|c|}{3.41} & \multicolumn{2}{|c|}{1.08} & \multicolumn{2}{|c|}{0.51} & \multicolumn{2}{|c|}{2.29} \\
\hline & \multicolumn{2}{|c|}{ Ratio (SST/AT) } & \multicolumn{2}{|c|}{$\begin{array}{c}\text { Phenolics } \\
\left(\mathrm{mg} \text { gallic ac. } 100 \mathrm{~g}^{-1}\right)\end{array}$} & \multicolumn{2}{|c|}{$\begin{array}{c}\text { Anthocyanins (mg } \\
\left.100 \mathrm{~g}^{-1}\right)\end{array}$} & \multicolumn{2}{|c|}{ Firmness (N) } \\
\hline Camarosa & $9.15 \mathrm{bA}$ & $6.48 \mathrm{bcB}$ & $172.44 \mathrm{abA}$ & $151.96 \mathrm{aB}$ & $15.78 \mathrm{bB}$ & $21.04 \mathrm{aA}$ & $11.10 \mathrm{aA}$ & $10.98 \mathrm{aA}$ \\
\hline Camino Real & $7.99 \mathrm{cA}$ & $7.72 \mathrm{aA}$ & $150.71 \mathrm{cA}$ & $124.99 \mathrm{bB}$ & $17.70 \mathrm{bA}$ & $19.96 \mathrm{aA}$ & $6.26 \mathrm{bB}$ & $9.88 \mathrm{abA}$ \\
\hline Monterey & $8.95 \mathrm{bA}$ & $6.77 \mathrm{bB}$ & $163.70 \mathrm{bA}$ & $148.27 \mathrm{aB}$ & $23.35 \mathrm{aA}$ & $9.99 \mathrm{bB}$ & $6.66 \mathrm{bB}$ & $8.46 \mathrm{bA}$ \\
\hline Albion & $10.20 \mathrm{aA}$ & $6.07 \mathrm{cB}$ & $183.64 \mathrm{aA}$ & $127.85 \mathrm{bB}$ & $8.50 \mathrm{cA}$ & $5.58 \mathrm{cB}$ & $6.48 \mathrm{bA}$ & $5.41 \mathrm{cA}$ \\
\hline Average & $9.07 \mathrm{~A}$ & $6.76 \mathrm{~B}$ & $167.62 \mathrm{~A}$ & 138.27 B & $16.33 \mathrm{~A}$ & $14.14 \mathrm{~B}$ & $7.62 \mathrm{~B}$ & $8.76 \mathrm{~A}$ \\
\hline CV (\%) & \multicolumn{2}{|c|}{2.36} & \multicolumn{2}{|c|}{3.2} & \multicolumn{2}{|c|}{10} & \multicolumn{2}{|c|}{10.18} \\
\hline
\end{tabular}

$\mathrm{w} / \mathrm{inoc}=$ with inoculant; wo/inoc $=$ without inoculant. Results are presented in average $(\mathrm{n}=3)$. Same lowercase letters in the column and uppercase letters in the line do not differ significantly, Tukey test $(\mathrm{p} \leq 0,05)$. 
Table 5. AMF radicular colonization (\%) in strawberry cultivars with mycorrhizal fungi in 2017. Guarapuava, UNICENTRO, 2018.

\begin{tabular}{lcc}
\hline Cultivar & w/inoc. & wo/ inoc \\
\hline Albion & $22.78 \mathrm{aA}$ & $7.62 \mathrm{bB}$ \\
Camarosa & $18.43 \mathrm{aA}$ & $6.68 \mathrm{bB}$ \\
Camino Real & $8.90 \mathrm{bA}$ & $7.61 \mathrm{bA}$ \\
Monterey & $19.41 \mathrm{aA}$ & $17.57 \mathrm{aA}$ \\
\hline CV (\%) & 24.68 & \\
\hline
\end{tabular}

$\mathrm{w} /$ inoc $=$ with inoculant; wo/inoc $=$ without inoculant. Results are presented in average $(n=3)$. Same lowercase letters in the column and uppercase letters in the line do not differ significantly, Tukey test $(\mathrm{p} \leq 0,05)$.

\section{3 and 4).}

The anthocyanin degree can be considered both as cultivar choice and as a cultivation system criterium, as it is considered one of the bioactive compounds that promote benefits to the health and appearance of the fruits (Calvete et al., 2008). According to Clifford (2000), the average values of anthocyanins in strawberries may vary between 15 and $35 \mathrm{mg} 100 \mathrm{~g}^{-1}$ of fruits, therefore, the values found in this research are within this range, regardless of mycorrhizal inoculation.

Baslam \& Goicoechea (2012), evaluating the capacity of mycorrhizal fungi to induce antioxidant compounds accumulation in lettuce leaves, observed that the use of AMFs has promoted the accumulation of carotenoids, phenolics and anthocyanins, thus increasing the nutritional quality of this vegetable. This fact may be observed in this study as well, where plants inoculated with these fungi have shown a greater degree of phenolics and anthocyanins (in 2017), when compared to treatments without inoculation, thus showing the efficiency of AMFs in promoting quality characteristics in strawberry fruits.

The firmness of strawberry fruits in 2016 was greater in the Camarosa, Aromas and San Andreas cultivars with AMF inoculation (Table 3). The effect of AMF inoculation to promote fruit firmness in 2016 was also observed in the general average of cultivars. However, in 2017 a contrary effect of AMF inoculation was observed, promoting less firm fruits (Table 4). Fruits firmness in 2016 varied from 8.30-14.07 N, while in 2017 it varied from $5.41-11.10 \mathrm{~N}$, the fruits being therefore less firm in 2017, possibly due to edaphoclimatic differences that vary from one year to another.

Studies developed by RiveraChávez et al. (2012) revealed that the use of AMFs exerts influence in the distribution of photoassimilates for strawberry fruits, in addition to improving their firmness. Corroborating this study, the improvement of fruit firmness in AMF-inoculated plants was observed in 2016, but not in 2017. In the same way, Cecatto et al. (2016) observed a firmness increase in strawberries only in fruits collected in the beginning of production. In fruits collected in a later production period there was no effect of AMF inoculation on firmness.

In 2017, the climatic conditions in the Guarapuava region were atypical, with lower than expected rainfall and greater heat in the second semester. The hotter and drier air may have contributed for lower fruit firmness both in inoculated and in non-inoculated plants, even when the plants were maintained with irrigation. The greater heat and solar radiation incidence, associated to less humid air during the significant rainless period, has accelerated the degradation of the cellular wall's pectic substances, responsible for fruit firmness, making the fruits less firm than those cultivated in 2016 .

The mycorrhizal colonization of strawberry plants was evaluated only in 2017 by the end of culture's productive cycle (Table 5). The colonizationpromoting effect AMF-inoculation had in the Albion and Camarosa cultivars was observed, but not in the Camino Real and Monterey cultivars, which did not differ between inoculated and non-inoculated plants. The evidence of the promotion of strawberry mycorrhizal colonization by AMF inoculation was observed, even after the final cycle of production, at nine months after inoculation, is a clear sign of the benefits of AMFinoculation in this culture. Along the cultivation time it is expected that the AMF native community multiplies in the rhizosphere and uniformizes the colonization between inoculated and non-inoculated plants (Janoušková et al., 2017). The mycorrhizal colonization levels observed in strawberries were between 7.61-22.78\% (Table 5), being considered low if compared to many native arboreal species (Carneiro et al., 1998), but being considered within the normal variation range in olericultures (Miller \& Jackson, 1998; Kim et al., 2000). In strawberry plants, Robinson Boyer et al. (2016) verified a variation in mycorrhizal colonization of $20-40 \%$ during the culture cycle, but by the end of the cycle plants were observed as almost without mycorrhizal colonization (average $<1 \%$ ).

Therefore, the beneficial results verified for most quality and post-harvest attributes of evaluated strawberry fruits may be attributed to benefits hailing from AMF inoculation in the planting of saplings. This benefit verified as well by the analysis of mycorrhizal colonization of the roots after the production cycle confirms the results.

In the present work, inoculation with AMFs of various strawberry cultivars in the field, has improved the quality of fruits, in their physicochemical attributes, increasing $\mathrm{pH}$, the soluble solids degree, the soluble solids/ titratable acidity and the degree of phenolic compounds in both cultivation years.

\section{REFERENCES}

BARTH, E; RESENDE, JTV; ZEIST, AR; MARIGUELE, KH; ZEIST, RA; GABRIEL, A; CAMARGO, CK; PIRAN, F. 2019. Yield and quality of strawberry hybrids under subtropical conditions. Genetics and Molecular Research 18: 01-10.

BASLAM, M; GARMENDIA, I; GOICOECHEA, N. 2011.Arbuscular mycorrhizal fungi (AMF) improved growth and nutritional quality 
of greenhouse-grown lettuce. Journal of Agricultural and Food Chemistry 59: 55045515.

BASLAM, M; GOICOECHEA, N. 2012. Water deficit improved the capacity of arbuscular mycorrhizal fungi (AMF) for inducing the accumulation of antioxidant compounds in lettuce leaves. Mycorrhiza 22: 347-359.

BENASSI, MT; ANTUNES, AJ. 1988. A comparison of metaphosphoric and oxalic acids as extractant solutions for the determination of vitamin $\mathrm{C}$ in selected vegetables. Arquivos de Biologia e Tecnologia 31: 507-513.

BONA, E; CANTAMESSA, S; MASSA, $\mathrm{N}$; MANASSERO, P; MARSANO, F; COPETTA, A; LINGUA, G; D'AGOSTINO, G; GAMALERO, E; BERTA, G. 2017 Arbuscular mycorrhizal fungi and plant growth-promoting pseudomonads improve yield, quality and nutritional value of tomato: a field study. Mycorrhiza 27: 1-11.

BONA, E; LINGUA, G; MANASSERO, P; CANTAMESSA, S; MARSANO, F; TODESCHINI，V; COPETTA，A; D'AGOSTINO, G; MASSA, N; AVIDANO, L; GAMALERO, E; BERTA, G. 2015. AM fungi and PGP pseudomonads increase flowering, fruit production, and vitamin content in strawberry grown at low nitrogen and phosphorus levels. Mycorrhiza 25: 181193.

CALVETE, EO; MARIANI, F; WESP, CL; NIENOW, AA; CASTILHOS, T; CECCHETTI, D. 2008. Fenologia, produção e teor de antocianinas de cultivares de morangueiro em ambiente protegido. Revista Brasileira de Fruticultura 30: 396-401.

CARNEIRO, MAC; SIQUEIRA, JO; MOREIRA, FMS; CARVALHO, DD; BOTELHO, SA; SAGGIN JUNIOR, OJ. 1998. Micorriza arbuscular em espécies arbóreas e arbustivas nativas de ocorrência no sudeste do Brasil. Cerne 4: 129-145.

CECATTO, AP; CALVETE, EO; NIENOW, AA; COSTA, RC; CONSTÂNCIO, HFC; MENDONÇA; PAZZINATO, AC. 2013. Culture systems in the production and quality of strawberry cultivars. Acta Scientiarum 35: 471-478.

CECATTO, AP; RUIZ, FM; CALVETE, EO; MARTÍNEZ, J; PALENCIA, P. 2016. Mycorrhizal inoculation affects the phytochemical content in strawberry fruits. Acta Scientiarum 30: 227-237.

CHIOMENTO, JLT; COSTA, RC; NARDI, FS; TRENTIN, NDS.; NIENOW, AA; CALVETE, EO. 2019. Arbuscular mycorrhizal fungi communities improve the phytochemical quality of strawberry. The Journal of Horticultural Science and Biotechnology 94: 1-11.

CLIFFORD, MN. 2000. Anthocyanins-nature, occurrence and dietary burden. Journal of the Science of Food and Agriculture 80: 1063-1072.

COPETTA, A; BARDI, L; BERTOLONE, E;
BERTA, G. 2011. Fruit production and quality of tomato plants (Solanum lycopersicum L.) are affected by green compost and arbuscular mycorrhizal fungi. Plant Biosystems - An International Journal Dealing with all Aspects of Plant Biology 145: 106-115.

EMPRESA BRASILEIRA DE PESQUISA AGROPECUÁRIA. 2013. Sistema brasileiro de classificação de solos, 3.ed. Brasília: Embrapa. 353p.

FERNÁNDEZ-LARA, R; GORDILLO, B; RODRÍGUEZ-PULIDO, FJ; GONZÁLEZ, LMM; MARTÍNEZ, AADV; DÁVILAORTIZ, G; HEREDIA, FJ. 2015. Assessment of the differences in the phenolic composition and color characteristics of new strawberry (Fragaria $x$ ananassa Duch.) cultivars by HPLC-MS and Imaging Tristimulus Colorimetry. Food Research International 76: 645-653.

GABRIEL, A; RESENDE, JTV; ZEIST, AR; RESENDE, LV; RESENDE, NCV; ZEIST, RA. 2019. Phenotypic stability of strawberry cultivars based on physicochemical traits of fruit. HorticulturaBrasileira 37: 75-81.

GIOVANNETTI, M; MOSSE, B. 1980. An evaluation of techniques to measure vesiculararbuscular mycorrhizal infection in roots. The New Phytologist 84: 484-500.

GIUSTI, MM; WROLSTAD, RE. 2001. Anthocyanins. Characterization and measurement with UV-visible spectroscopy. In: WROLSTAD, RE (eds). Current protocols in food analytical chemistry. New York: Editora John Wiley \& Sons. p.13-21.

HASHEM, A; A L Q A R AWI, A A ; RADHAKRISHNAN, R; AL-ARJANI, A-BF; ALDEHAISH, HA; EGAMBERDIEVA, D; ABD_ALLAH, EF. 2018. Arbuscular mycorrhizal fungi regulate the oxidative system, hormones and ionic equilibrium to trigger salt stress tolerance in Cucumis sativus L. Saudi Journal of Biological Sciences 25: 1102-1114.

HENSCHEL, JM; RESENDE, JTV; LIMA, PCG; ZEIST, AR; LIMA FILHO, RB; SANTOS, MH. 2017. Production and quality of strawberry cultivated under different colors of low tunnel cover. Horticultura Brasileira 35: 364-370.

IAL. INSTITUTO ADOLFO LUTZ. 2005. Métodos físico-químicos para análise de alimentos. Brasília: Secretaria de Estado da Saúde. 1000p.

JANOUŠKOVÁ, M; KRAK, K; VOSÁTKA, M; PÜSCHEL, D; ŠTORCHOVÁ, H. 2017. Inoculation effects on root-colonizing arbuscular mycorrhizal fungal communities spread beyond directly inoculated plants. Plos One 12: e0181525.

KIM, Y; EOM, AH; TAE, MS; LEE, SS. 2000. The observation of arbuscular mycorrhizal roots in horticultural plants. Mycobiology 28: 1115-1118.

MILLER, RL; JACKSON, LE. 1998. Survey of vesicular-arbuscular mycorrhizae in lettuce production in relation to management and soil factors. Journal of Agricultural Science 130: 173-182.

PANDEY, D; KAUR, P; DEY, A. 2018. Arbuscular mycorrhizal fungi: Effects on secondary metabolite production in medicinal plants. In: GEHLOT, P; SINGH, J (eds). Fungi and their role in sustainable development: Current perspectives. Singapore: Springer. p.507-538.

RIVERA-CHÁVEZ, FH; VÁSQUEZ-GÁLVEZ, G; CASTILLEJO-ÁLVAREZ, LH; ANGOAPÉREZ, MV; OYOQUE-SALCEDO, G; MENA-VIOLANTE, HG. 2012. Efecto de hongos micorrícicos arbusculares y extracto acuoso de vermicompost sobre calidad de fresa. Ra Ximhai 8: 119-130.

ROBINSON BOYER, L; FENG, W; GULBIS, N; HAJDU, K; HARRISON, RJ; JEFFRIES, P; XU, X. 2016. The use of arbuscular mycorrhizal fungi to improve strawberry production in coir substrate. Frontiers in Plant Science 7: 1237-1237.

SAGGIN JUNIOR, OJ; SILVA, EMR. 2005. Micorriza arbuscular: Papel, funcionamento e aplicação da simbiose. In: AQUINO, AM; ASSIS, RL (eds). Processos biológicos no sistema solo-planta: ferramentas para uma agricultura sustentável. Brasília: Embrapa Informação Tecnológica; Seropédica: Embrapa Agrobiologia. p.101-149.

SOARES, ADB; GOMES, MLPA; MESQUITA, CH; LAJOLO FM. 2004. Ascorbic acid biosynthesis: a precursor study on plants. Brazilian Journal of Plant Physiology 16: 147-154.

TODESCHINI, V; AITLAHMIDI, N; MAZZUCCO, E; MARSANO, F; GOSETTI, F; ROBOTTI, E; BONA, E; MASSA, N; BONNEAU, L; MARENGO, E; WIPF, D; BERTA, G; LINGUA, G. 2018. Impact of beneficial microorganisms on strawberry growth, fruit production, nutritional quality, and volatilome. Frontiers in Plant Science 9: 1611-1611.

WILLIANS, S. 1984. Official methods of analysis of the association of official analytical chemists. Arlington: AOAC. 1141p.

WOISKY, RG; SALATINO, A. 1998. Analysis ospropolis: some parameters ondprodecore for chemical fuality control. Journal of Apicultural Research 37: 99-105.

WREGE, MS.; STEINMETZ, S.; REISSER JUNIOR, C.; ALMEIDA, IR. 2011. Atlas climático da Região Sul do Brasil: Estados do Paraná, Santa Catarina e Rio Grande do Sul. 1 ed. Pelotas: Embrapa Clima Temperado. Colombo: Embrapa Florestas. 336p.

XU, Y; XU, Q; HUANG, B. 2015. Ascorbic acid mitigation of water stress-inhibition of root growth in association with oxidative defense in tall fescue (Festuca arundinacea Schreb.). Frontiers in Plant Science 6: 807-807.

ZEIST, AR; RESENDE, JTV. 2019. Strawberry breeding in Brazil: current momentum and perspectives. Horticultura Brasileira 37: 7-16. 